\title{
DECONSTRUCTING THE TEXTUAL REPRESENTATION OF THE FATHERS IN THE FANTASY PICTUREBOOK ONE DAD, TWO DADS, BROWN DAD, BLUE DADS (1994)
}

\author{
DECONSTRUYENDO LA REPRESENTACIÓN \\ TEXTUAL DE LOS PADRES EN EL LIBRO ÁLBUM \\ DE FANTASÍA ONE DAD, TWO DADS, \\ BROWN DAD, BLUE DADS (1994)
}

\author{
MARÍA MARTÍNEZ LIROLA \\ Universidad de Alicante and University of South Africa \\ maria.lirola@ua.es
}

\begin{abstract}
This paper aims to explore the linguistic and visual choices used by the writer and the illustrator in order to create meaning in the fantasy picturebook One Dad, Two Dads, Brown Dad, Blue Dads (1994), written by Johnny Valentine and illustrated by Melody Sarecky, which features a gay family.

The analytical tools employed in this study to deconstruct meanings in the said picturebook are Kress and van Leeuwen's (2006) Visual Social Semiotics and Painter et al.'s (2013) model to read visual narratives in children's picturebooks. The analysis concentrates on the textual and compositional metafunctions in order to observe the intersemiotic relationship between verbal and visual meanings and their realizations through various linguistic and visual modes. The methodology is qualitative-descriptive.

One Dad, Two Dads, Brown Dad, Blue Dads reveals that both visuals and written text narrate the story, although it is the visual that is given a predominant role on the page due to its size, the location of the characters and the frames. The analysis shows that this is a picturebook in which having two fathers is represented as nonnormalized, although they perform their family duties as they are expected to because they do the same things that other fathers do.
\end{abstract}

Keywords: children's picturebooks, multimodality, Systemic Functional Grammar, two-father families. 


\section{Resumen}

Este artículo tiene como objetivo explorar las elecciones lingüísticas y visuales utilizadas por el escritor y el ilustrador con el fin de crear significados en el libro ilustrado donde aparece una familia gay One Dad, Two Dads, Brown Dad, Blue Dads (1994), escrito por Johnny Valentine e ilustrado por Melody Sarecky.

Las herramientas analíticas empleadas en este estudio son la Semiótica Social Visual de Kress y van Leeuwen (2006) y el modelo de Painter et al. (2013) para leer narrativas visuales en libros álbum con el fin de deconstruir significados en el libro ilustrado mencionado. El análisis se centrará en la función textual y composicional para observar la relación intersemiótica entre los significados verbales y visuales y sus realizaciones a través de diversos modos lingüísticos y visuales. La metodología es cualitativa-descriptiva.

One Dad, Two Dads, Brown Dad, Blue Dads revela que tanto las imágenes como el texto escrito narran la historia, aunque es lo visual lo que tiene un papel predominante en la página debido a su tamaño, la ubicación de los personajes y los marcos. El análisis muestra que se trata de un libro ilustrado en el que tener dos padres se representa como no normalizado, aunque realizan sus actividades familiares de manera esperada pues hacen las mismas cosas que el resto de los padres.

Palabras clave: libros ilustrados, multimodalidad, gramática sistémica funcional, familias con dos padres.

\section{Aims and Scope of the Study}

Literature for children not only contributes to introducing children to literacy but also to their process of socialization and the development of their ideology. The competences of reading and writing are developed with children's picturebooks (Soto Reatiga 2017). Moreover, the fact that picturebooks are full of cultural references promotes children's acquisition of cultural competences (Nikolajeva and Scott 2001; Arizpe et al. 2013; Evans 2015). This has an effect on the way children understand the world and incorporate cultural patterns while they learn (Painter 2018).

In addition, children have to acquire multiliteracies and need to learn strategies to understand how meaning is created by the combination of image and words. In this sense, children have to explore both modes. Following Hoster Cabo et al., " $[t]$ he picturebook is a place of communication where readers perceive visual as well as verbal signs. Furthermore, readers are invited to explore them, thus making their own hypothesis regarding the picturebooks' meaning" (2018: 91). 
One Dad, Two Dads, Brown Dad, Blue Dads (1994), written by Johnny Valentine and illustrated by Melody Sarecky, has been chosen as an example of a fantasy book used to portray a gay family. The story is simple: a girl asks questions to a boy who has two blue dads in order to see if they can do the same things as fathers who are not blue and to know how they became blue. This picturebook is designed for 4-8-year-old children to open them up to the idea of different types of fathers: the combination of a different colored dad, a traditional family and a family with two dads helps children to compare different types of dads in order to discover that they are not that different in the end.

Moreover, this picturebook has been chosen because it comes within the first of the different textual strategies proposed by Sunderland and Mclashan (2012: 162170) for the promotion, acceptance, understanding or celebration of families with same-sex parents: the 'different' strategy "where having two Mums or Dads is conceptually recognised as different by the child" (Sunderland and Mclashan 2012: 165). Additionally, these authors propose the 'backgrounding' strategy: "[t] hese books do not address the issue of gay sexuality directly or even indirectly, but rather issues surrounding the family or personal life, which are not specific to gay families" (Sunderland and Mclashan 2012: 168); and the 'gay' strategy, where "gay sexuality is discussed explicitly, in part through the device of explaining the word to the child in the story" (Sunderland and Mclashan 2012: 163).

The purpose of this study is to deconstruct the way gay families are represented as different from both the linguistic and visual points of view, paying attention to the textual metafunction of the picturebook. In this sense, the aim is to discover the intersemiotic relationship between visual and linguistic meaning and their realizations through various modes.

The rest of the paper is organized as follows: section two presents a literature review, section three offers an analysis of the picturebook, concentrating on the textual metafunction, section four contains the discussion and section five sets out some conclusions.

\section{Literature Review}

Language and other resources in multimodal or multisemiotic phenomena such as websites or videos are called 'semiotic resources', 'modes' and 'modalities'. Following Thibault (2000), Ventola and Moya Guijarro (2009) and Parodi (2012), among others, I understand that all texts have a multisemiotic nature.

The theory of multimodality and multimodal discourse analysis (hereafter MDA) has been developed in recent decades. O'Halloran (2011: 120) specifies: "MDA 
itself is referred to as 'multimodality', 'multimodal analysis', 'multimodal semiotics' and 'multimodal studies"'. Hestbæk Andersen et al. state that:

\begin{abstract}
'Multimodality' and 'mode' have also been used rather loosely and defined rather perfunctorily. We can say, as Gunther Kress does in Multimodality (2010), that multimodality is a phenomenon rather than a discipline - the phenomenon that communication integrates a range of means of expression simultaneously. But perhaps this is not entirely correct, because other disciplines use other terms for the same phenomenon, like intermediality and multisensoriality. So, 'multimodality' is also a disciplinary position, an approach to the study of the phenomenon that hails from linguistics and semiotics. (2015: 101)
\end{abstract}

Children's picturebooks are multimodal, i.e. the image and the written text interact in the creation of meaning. The relationship between the written text and the visual to create meaning in these books has been studied by scholars such as Lewis (2001), Painter (2007, 2008), Unsworth and Ortigas (2008), Serafini (2010), Unsworth (2014) and Moya Guijarro (2014, 2019a, 2019b).

The model of visual semiotics proposed by Kress and Van Leeuwen (2006) is based on the metafunctions that Halliday proposed in Systemic Functional Linguistics, i.e. ideational, interpersonal and textual (Halliday and Matthiessen 2004). These metafunctions pay attention to ideational meanings (the way realities are represented in texts), interpersonal meanings (the social relations between characters and with the readers) and textual meanings (the way texts are coherent and establish relationships with their context). Kress and van Leeuwen (2006) refer to the metafunctions as representational, interpersonal and compositional.

Multimodal discourse analysis allows readers to explore the relationship between the image and the written text in order to deepen their understanding of the construction of meaning. The textual function refers to the written mode and the compositional function refers to the visual one, following van Lierop-Debrauwer (2018: 82): "Although words and pictures in picturebooks always convey meaning together, each of the two sign systems has its own potential in contributing to the story, in expressing temporality, spatiality, narrative perspective, and characterization".

Regarding the textual metafunction, I will refer to theme (i.e. the first element in a clause) and rheme (i.e. what follows the theme) when analysing the written text, following Halliday and Matthiessen (2004: 64): "The theme is the element which serves as the point of departure of the message; it is that which locates and orients the clause within its context".

The textual analysis is relevant to see the characters who appear in a prominent position in the written text and to analyse if the written theme coincides with the visual one. Mathesius defines these concepts in the following way: 
The element about which something is stated may be said to be the basis of the utterance or the theme, and what is stated about the basis is the nucleus of the utterance or the rheme. [...] The basis of the utterance (the theme) is often called the psychological subject and the nucleus (the rheme) the psychological predicate. (1975: 81)

Themes can be marked when they do not coincide with the subject in a declarative sentence, when there is a subject before the verb in an imperative, when there is a complement before the finite in a polar interrogative or when we find a non WHsubject in a WH-interrogative (Halliday and Matthiessen 2004). In addition, Daneš (1974: 118-123) proposes three types of thematic progression (TP): a) "Simple linear TP", where each rheme becomes the theme of the next sentence; b) "TP with a continuous (constant) theme", i.e. we find the same theme in different clauses but the rheme is different; and c) "TP with derived Ts": the text has a general theme and the different themes derive from that general theme although they are not the same.

I will also concentrate on the compositional metafunction in this article because it integrates ideational and interpersonal meanings by illustrating how meanings are packaged into units of information on the page. According to Kress and van Leeuwen (2006: 177), there are three main types of composition in multimodal texts: a) 'Information value': the place in which elements are located, for example, from left to right, from the top to the bottom or from the centre to the margins, can add a determined value; b) 'Salience': the different elements of a composition which are designed to catch the readers' attention, for example, appearing in the first or in the second place, the size of an element, the colour contrast or sharpness; and c) 'Framing': the presence or absence of frames that connect or disconnect elements of meaning by whether they go or do not go together in the making of meanings.

The layout of the page shows how the written language and the visual cohere to express meanings. An analysis of the main principles of composition and the distribution of the information value allows the deconstruction of the relationships between the different elements in the visual by observing different aspects such as the placement of elements on the right (new information) and on the left (given information) and the size of the images and the frames (Kress and van Leeuwen 2006). In addition, the elements in the upper part of the layout function are considered as 'ideal', whereas those in the lower position function are 'real'.

Following Painter et al. (2013), layouts can be complementary when the written text and the visuals appear in their own space, indicating that they have a different role in the construction of meaning. Moreover, layouts are integrated when image and words come together. 
The size of elements also contributes to the foregrounding of characters; a small character placed near the bottom of the page is given less importance than those that are large and centred. As regards framing, images are 'unbound' when there is no margin enclosing them, i.e. the only boundary is the page edge. In contrast, 'bound' images are set within a page margin, which separates readers from the story.

Each unit of information in a visual text is considered a 'focus group' (Painter et al. 2013: 91). A focus group can be placed around the centre in various ways, or it can be repeated in a series across the image (iterating). Iterating focus groups can be a) centrifocal, when they are placed around the centre, and within this option, centrifocal centred when the centre of the space is filled or centrifocal polarized when different elements are opposed on a diagonal, vertical or horizontal axis; or b) iterating, when elements are repeated across the image, normally in regular lines.

\section{Analysis}

One Dad, Two Dads, Brown Dad, Blue Dads is a clear example of a fantasy book, as we can see from the title. The two fathers are referred to as blue, a colour traditionally associated with men. In this way, from the beginning of the book having two fathers is presented as non-normalized in the sense that it is highlighted that Lou's (the blue dads' son) fathers are different from other fathers due to their colour. This picturebook starts representing one dad at the top and two dads at the bottom. The next page specifies that one is a brown dad and the others are blue. The three of them appear walking with their dogs.

The two blue dads are shown from the start as having different styles. One is wearing casual clothes, sport shoes, sunglasses and has a moustache while the other, placed on the right of the page, is wearing blue trousers, a white shirt and brown shoes. The representation of the fathers as blue is highlighted from the very beginning of the story, where the word 'blue' appears several times. It is significant that it is capitalized, so that readers can immediately identify that they are not conventional fathers.

The fathers are referred to as dads or as blue dads throughout the book, with the exception of illustration 8 , where one of the dads is referred to with pronouns in order to make clear that the action of cooking is done by only one of them: "My dads both play piano, and one of them cooks. (He makes wonderful chocolate cream pies)".

\subsection{Exploring Information Value and the Representation of the Fathers}

In this picturebook, the double-page spread is considered as a single layout unit with a clear division between left and right, the right showing the most important 
part of the information. Whenever Lou and the girl asking him questions throughout the book appear, they are on the right page because they introduce new information: either the girl asks new questions, or Lou offers her an answer that provides her with new information. However, there are two exceptions to this pattern of organising the information value of the images, one at the beginning and one at the end of the story: 1) in illustration 3 Lou and the girl are on the left and the blue fathers on the right, which highlights the latter; 2) in illustration 15 a new girl called Jean appears in the story; the fact that she appears on the right helps to emphasize her.

In illustration 3 , Lou points to the blue fathers with his left hand while he says:

"I do!

My name is Lou.

I have two dads

Who both are blue".

These words show that the written rheme is in the visual on the right, as a way of giving importance to both fathers. This is the moment when Lou confirms that he has two blue dads.

Illustration 3 in the book is the second time that the two blue dads are represented together. The dad wearing smart clothes in the previous visual is wearing the same clothes, but here he is touching his tie with one hand and holding a smart hat with the other as a sign of greeting. The other blue dad, who is on the right in contrast with the one presented on the previous page (who was on the left), is wearing grey trousers, shoes and a jacket, but he is also wearing a red t-shirt as in the previous visual. He is saying 'hi' with a simple arm gesture. Here he is not wearing sunglasses and instead of a moustache he has a beard, which is a sign of masculinity. This is the first page where Lou appears, and we can see that he has black hair and that the colour of his skin is black. This shows that the book is not only about a two-father family but also about a family in which there are people of different racial origins. This contributes to promoting the integration of people from different races. Combining race and sexual orientation in a picturebook like this helps to foreground differences in families and the importance of acceptance of and respect towards these differences.

In this illustration, pets have a significant role. There is a cat behind the legs of the father with the beard and a dog between Lou and the father with glasses. Lou's $\mathrm{t}$-shirt is red and white, i.e. a mixture of the colours of the t-shirt and shirt of the two fathers, and a clear way of pointing out the relationship among the three characters. Lou has one arm on his chest while the other arm is pointing to the fathers on the next page. This is significant because it guides readers' attention to the fathers, who are given importance by appearing on the right page. At the same 
time, Lou is looking at the girl who expressed her surprise at the existence of blue dads on the previous page:

\author{
"Blue dads? \\ BLUE dads!? \\ I don't know who \\ has dads that are blue!"
}

In illustration 4 , the father with the beard is at the bottom of the page, showing that his body is blue. The other father is at the top of the page, combing his blue hair. The next illustration shows the child who narrates the story asking Lou the following questions: "'What is it like to have blue dads?' I said./ 'Do they talk? Do they sing?" "Next to the girl's head is a bubble with the heads of the two dads singing and some musical notes coming out of their mouths. In this visual, the cat between the two children clearly indicates a division between them. In fact, Lou is situated on the right of the page, the place of new information, emphasizing that he is the character who will have to answer the questions asked by the girl on the left.

In illustration 5 the father with the beard is holding a dish of cookies while the other one is lying in bed eating a cookie. As on the previous page, he is not wearing glasses but they are visible on the bedside table and in the previous visual next to the mirror. The right page of illustration 5 is very important in terms of the relationship of meaning between the written text and the visual, because we find the following questions next to an image of the father: "Do they work? Do they play? Do they cook? Do they cough?" The first and third questions appear next to the father with glasses; the second and fourth appear next to the father with the beard. It is significant that it is the same dad (the one with glasses) who is represented doing the two productive activities, working and cooking, illustrated on the left next to the question on the right. In contrast, the other father, the one with the beard, appears playing and coughing on the right, while the written question is on the left. In this illustration, the characters appear in the same line as the written text, and there is a zigzag pattern that links both fathers at the same time with the father with glasses on the left and the one with the beard on the right.

Illustration 6 shows physical contact between the two fathers and Lou: they are shown very close to each other (Lou is between the two dads). The father with glasses is hugging Lou, and the other father is just touching his head with one hand while touching the dog with the other. It seems that the father with glasses is more affectionate than the father with the beard. Traditionally, cooking and open expressions of affection are associated with women. In this sense, it is remarkable how the father who hugs Lou and cooks is portrayed, in that he also works and is actually the one visually represented working outside the home. 
Next, Lou and the girl are represented walking one after the other over the curb, followed by the cat. On the next two pages we find the girl on the right, with a gesture that shows that she is thinking. The written text reflecting what she is thinking about appears above her:

"My dad can stand on his head", I told Lou.

"My dad plays me songs on his purple kazoo.

He even knows how to make chocolate fondue!

Can blue dads do all those things too?"

In illustration 7 , on the left, there is a visual showing the girl's father doing all the things mentioned in the text: he is standing on his head, playing songs on a kazoo and making chocolate fondue. There are different vectors between the father and the other page, where the girl is just thinking: the father's feet are pointing to the written text, and the chocolate fondue is clearly framing the image of the girl on the next page.

In the following illustration (8), Lou's dads are represented doing two very different actions: the father with glasses is on the right-hand page above the written text coming out of the kitchen carrying the chocolate cream pie he has just made. $\mathrm{He}$ is wearing an apron and a chef's hat. On the left-hand page, the father with the beard is playing the piano next to the dog, whose tail appears on the right-hand page, next to the written text where Lou explains that cooking is only done by one of his dads.

Illustration 9 shows the blue dads standing on their heads; they are clearly joined by vectors from the heads to the feet. The father with glasses is playing with some balls on his feet while the father with the beard is holding a newspaper that covers part of his body. Lou and the girl appear on the right of illustration 9. This time Lou has the cat around his neck with its tail between the two children pointing towards the girl who always asks questions, specifically towards one of her hands that is inside a fishbowl and towards the question she is asking, which appears above both children:

\footnotetext{
"What I would like to know now",

I went on to say

"is, just how did your dads

end up looking this way".
}

The following visuals in the picturebook illustrate the different suggestions that the girl has for both dads being blue, something that she considers very strange. The written text is located above a washing machine with both fathers inside on the right of illustration 10 . The left of this illustration shows two pictures of both fathers being children and already blue. These visuals are reinforcing the message expressed by the written text: 
"Did they go through the wash

With a ballpoint pen?

Or were they both blue

Since the young age of ten?"

In illustration 11, there are two more questions with possible suggestions for the dads being blue. In this case, the father without glasses is shown drinking blueberry juice as a boy, below the written text on the left page. He appears next to the dog and surrounded by a few toys. He is joined by vectors to the father on the right of the illustration, above many blue toys and carrying an airplane in his right hand:

"Did they drink too much blueberry juice as young boys?

Or as kids, did they play

With too many blue toys?”

Then, as usual in this picturebook, Lou offers an answer to the girl's questions in an illustration (number 12). In this case, the written text on the left page is placed at the top of the page above the fishbowl that appeared previously in the book:

"Just where did you get

all these questions!?” Lou said.

"How did such explanations

pop into your head?

They were blue when I got them

and blue they are still.

And it's not from a juice

or a toy, or a pill".

Lou is with the girl on the right page; the cat is again between them, and his tail surrounds a photograph showing Lou with his two dads. The written text with Lou's explanation about why both fathers are blue also appears at the top of the page, as in the previous case:

"They are blue because — wellbecause they are blue.

And I think they are

remarkable fathers — don't you?"

In illustration 13, almost at the end of the book, both dads are represented all in blue against the sky, hanging from a balloon. It is the father with glasses who is on the left page looking at the readers. There are vectors between him and the written text that appear in the left-hand corner of the illustration, where Lou's statement clearly confirms that his dads are unusual because they are blue: 
"Yes, my dads both are blue, and although you may try, it is hard to see blue dads against a blue sky".

On the right-hand page, the father without glasses is looking at a red bird that appears right in the middle of the illustration. On his right, the dog is hanging from a balloon, looking at the readers showing surprise. Finally, the last colored element on the page is a green bird in the corner of the right-hand illustration, next to the dog. The two colored birds and the dog contribute to highlighting the blue colour of both dads and the rest of the page, which is also blue.

The next illustration, number 14, shows Lou's dads in the centre of the page, surrounded by other dads who are brown, white or green. At the bottom of the page we find the written text with Lou's words expressing the normalization of his family:

"But except for that problem, our life is routine, and they're just like all other dadsblack, white, or green".

At the end of the book green dads are introduced. The two children appear again on the right of illustration 14, clearly foregrounded looking at each other. In the background there is a green dad holding a frog in his hand. In this case, the written text is at the top of the page, and it expresses the girl's surprise about the existence of green dads:

"Green dads? GREEN" dads!?

That I never have seen.

Now I never have seen

a dad who was green!"

The book ends with the introduction of a new character in the story depicted in illustration 15: a girl who has green dads. The girl who recognizes having a green dad is on the right, confirming that she is introducing new information in the picturebook. It is significant that she is wearing red trousers and a white shirt, the colours of Lou's t-shirt. This is a way of connecting both characters whose fathers are of different colours. The fact that she has a thematic/prominent position in the visual text corresponds to the topical theme in the written text:

"I have!

My name is Jean.

My dad's not blue.

I have two dads

who both are green". 
Moreover, Jean is emphasized because she is a new character in the story, saying that she has a green dad. In this sense, it is observed that the idea in this fantasy book of foregrounding dads of different colours is present from the beginning to the end of the story.

The fact that she introduces new information in the story through the written text corresponds to her position in the layout: her presence as a character bringing new information is reinforced the first time she appears, on the right side of the layout, because she is with Lou and the girl who always asks questions - Jean is on the right and Lou and the girl on the left. There is physical space between Jean and the other two children, whose arms are touching. Finally, she is represented alone on the right side of the page layout, in the very last illustration of the book. The representation of the girl moving away, giving her back to the readers and showing only part of her face, contributes to showing that this is the end of the story, as the written text also makes clear:

"I'd love to let you take a look.

But we've run out of room now, in this little book".

Jean, Lou and the girl who has asked questions throughout the book appear on green grass in illustration 15 as a way of pointing out the new topic that has just been introduced in the story: the fact that Jean has green dads. In illustration 15, the written text is also at the top of the visual and Jean appears alone. The hand of the new girl points to the ground as a way of closing the story. The written text makes clear that explaining aspects of green dads would require another book (see the previous quotation).

\subsection{Contrasting the Position of the Fathers in the Illustrations and Portraying their Normalization}

The father with the beard is on the right in several illustrations $(3,5,6,13$, and 14) while the one wearing glasses is on the right in several others (illustrations 1 , $2,4,8,9,10$, and 11), so both dads appear in the prominent position throughout the picturebook. However, the fact that the dad with glasses is the one who cooks (illustrations 5 and 8 ) and works outside the home (illustration 5 ) suggests that he is given more importance. Moreover, the written text states that he is the one in charge of cooking, which suggests that there is a clear division of tasks as traditionally happens in heterosexual couples. This contrasts with the way that the father with the beard is represented: there is no linguistic or visual reference to him working outside the home; he is represented playing with the pets (illustration 5), offering the other dad some biscuits (illustration 5) and playing the piano (illustration 8). Consequently, he is more connected with less productive activities 
than with working and cooking, and his expression of affection towards Lou is less open than that of the other dad (illustration 6).

Although both dads are different from most dads because they are blue, they are represented visually doing normal actions such as cooking and working, so that they can be seen as a normal family. In this sense, this picturebook contributes to the construction of two-father families as normalized, which will benefit the socialization of the child in this kind of family as being like any other child. Being blue is considered by Lou a fact in illustration 12. Moreover, apart from accepting them as they are, they are referred to as remarkable, an adjective with positive connotations:

"They are blue because —wellbecause they are blue.

And I think they are remarkable fathers — don't you?"

It is interesting that the normalization of the life that Lou lives with his two dads highlighted throughout the story contrasts with the fact that he refers to them being blue as a problem in illustration 14 :

"But except for that problem, our life is routine, and they're just like all other dadsblack, white, or green".

\subsection{Exploring the Patterns Combining the Written Text and the Visual, Framing and Focus Patterns}

In most cases in this picturebook, the written text is located at the top of the page centred in such a way that it is given weight. The most general pattern is a complementary vertical layout. There are only five illustrations where the written text appears below the visual, which gives the visual more importance. In other cases, the text is next to the visual. For example, the right-hand side of illustration 5 shows written questions next to the illustrated actions that the fathers are doing: "Do they work?" appears next to the father who is working and "Do they play?" appears next to the father who is playing with the dog.

As regards framing, the visuals in this book are unbound because the image extends on the illustration without any specific margin. The only boundary is the page edge. In this way, attention is given to each of the specific moments represented between the child and the fathers. I agree with Painter et al. (2013: 105) that " $[\mathrm{t}]$ he depicted characters are less constrained by their circumstances $[\ldots]$ and the story world is more opened up to the reader". 
The main focus pattern found in this book is iterating aligned because "[...] the elements are nearly always organized in fairly regular 'lines" (Painter et al. 2013: 111). However, there are examples of centrifocal polarized focus patterns in some cases where the child and one of the fathers represented on two sides of the page are joined by different vectors (illustrations 11 and 13); also when the two fathers are represented as children and one of them is drinking blueberry juice and the other is playing with blue toys (illustration 11).

\subsection{Analysing Theme and Rheme}

Taking into consideration the theme-rheme structure of the written text, it is observed that most of the themes are unmarked (78.43\%): they are the subject in declarative sentences; 'Blue dads', 'they', 'my dads' or 'my dad' constitute $31.37 \%$ of the themes; ' $\mathrm{I}$ ' is the theme in $11.76 \%$ of the cases. In this sense, we find examples of constant themes (Daneš 1974), which is a way of reiterating given information so that the child can follow the plot, for example the $\mathrm{WH}$-word as the theme in WH-questions such as "What is it like to have blue dads?" These represent just $7.84 \%$ of the total number of themes. Finally, the finite + subject is the theme in a polar interrogative clause, such as: "Do they talk? Do they sing?" These make up $27.45 \%$ of the examples analysed. Simple themes are the most common, as Table 1 shows.

\begin{tabular}{lcc}
\hline Themes & Absolute values & Values in percentages \\
\hline Simple theme & 41 & $80.40 \%$ \\
Multiple themes & 10 & $19.60 \%$ \\
Total number & 51 & $100 \%$ \\
\hline
\end{tabular}

Table 1. Types of themes

The rest of the themes are marked ${ }^{2}$, as evidenced by the addition of textual themes such as 'but' or 'and'. The following example shows that the fronting of the attribute 'blue' reinforces the continuity of the fathers being blue: "They were blue when I got them and blue they are still". The examples of marked themes appear at the end of the book; one example is the child referring to the fact that the fathers are blue as a problem:

"But except for that problem, our life is routine, and they're just like all other dadsblack, white, or green". 
Finally, once the possibility of fathers being green is introduced, the fronting of the object 'that' and the repetition of 'I never have seen' highlights that this is a new idea for the child who has asked Lou questions throughout the book:

"Green dads? GREEN dads!?

That I never have seen.

No, I never have seen

a dad who was green!".

The written theme coincides with the visual one: when the theme is ' $\mathrm{I}$ ', the visual shows Lou or the girl who asks him questions, and when the theme is the fathers, they appear in the visual. Out of the thirty pages in the book, both fathers appear together in fourteen cases, $46.66 \%$. If we pay attention to the position of the fathers on the page, both appear on the right the same number of times (seven each), which gives them equal importance. Both fathers are visual themes whenever they appear foregrounded on the page because of being on the right, in the centre or for their size.

\section{Discussion}

This book highlights the importance of tolerance, no matter how different people in general or fathers in particular are, in this case whether they are blue, green, etc. The representation of a colored dad, of homosexual parents, of a traditional family and the discussion among the children makes clear that all fathers can do the same things, no matter how different they are.

However, it is also observed that this picturebook offers a very clear example of both dads having different roles because the same dad is represented cooking twice in the visuals (illustrations 5 and 8 ). The fact that the dad with glasses is represented on the right, coming from the kitchen with a cream pie in his hand, while the other is playing the piano, clearly shows the division of tasks (illustration 8). There are different vectors between the two dads that reinforce the relationship between them. In addition, representing the dad with the beard playing the piano with his back turned while the one who has been cooking appears coming out of the kitchen towards the sitting room suggests that the father with glasses has more importance and a more active role in the family.

This book is clearly framed within the 'different' strategy (Sunderland and Mclashan 2012: 165) because it uses the metaphor of the two fathers being blue to highlight that they are different, although they can do the same things that straight fathers can do. In this picturebook, Lou is questioned by another child, a girl of a similar age as Lou, about his two blue fathers and about the fact that they 
are different. When the girl explains what her father can do, she appears on the right-hand page with the written text above her head, and the father is illustrated performing the different actions he can do on the left-hand page:

"My dad can stand on his head", I told Lou.

"My dad plays me songs on his purple kazoo.

He even knows how to make chocolate fondue!

Can blue dads do all those things too?"

"Do you think dads are different,

because they are blue?

My dads both play piano,

and one of them cooks.

(He makes wonderful chocolate cream pies)".

The representation of both fathers as blue is a textual strategy used to foreground them throughout the story and make them salient to the audience; in this sense, color is understood as a social phenomenon (Pastoreau 2008; van Leeuwen 2011). Following Painter et al. (2013: 35), "repetition of a colour may be used cohesively as a kind of visual rhyme to link different parts of a narrative". Consequently, the blue colour is a textual strategy used to give cohesion to the story. Making explicit that both fathers are blue suggests certain characteristics: blue is traditionally associated with men and pink with women. Using blue for both fathers is connected with their masculinity. Highlighting that the different parts of their bodies are blue makes explicit that their masculinity as gay men is also a characteristic of their personality:

"They both have blue hair,

that's the colour it grows.

Blue arms and blue fingers. Blue legs and blue toes".

In the previous examples, the idea being pointed out is that gay dads are as good as straight dads. Lou makes clear that his fathers can do what other fathers do although they are blue. In this sense, this picturebook refers to both dads as nonnormalized only in the sense that they are represented as blue. The word "gay" is not used; however, Lou's friends ask him all sorts of questions to see if his fathers do the things other fathers do:
"Do they work?
Do they play?
Do they cook?
Do they cough?"

In fact, Lou's answers to the questions that the girl asks him about his dads contribute to the construction of his family as normal due to the normal actions that they engage in. The answers provided help to normalize both blue fathers by pointing 
out that they work, play and laugh as any other father does. The written text consisting of Lou's answers to the girl's questions appears at the top of the page:

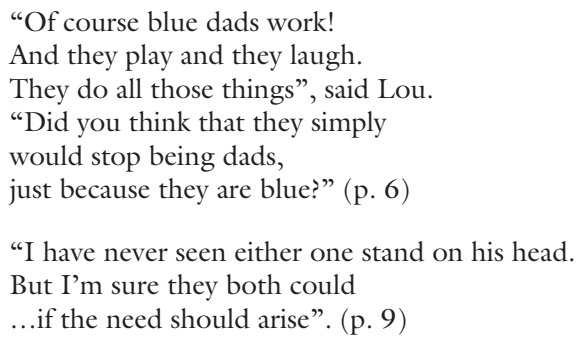

The last visual shows the two blue dads with the child holding hands being followed by two dogs. Ending the book in this way highlights that Lou's family is a happy family similar to any other, with the exception of both fathers being blue. The normalization of both fathers is foregrounded in this book in the multimodal combination of the written and visual text.

Pets appear throughout the book: in the visual where we find the brown dad at the top of the page and the two blue dads at the bottom, the three are represented next to a dog. The role of pets throughout the story serves to connect characters and to show affection. The fact that pets appear in different visuals contributes to the continuity of the story. In illustration 3 , both pets are used to establish connections between the characters on both pages.

This picturebook contributes to the normalization of two-men families, because the child emphasises that the two dads can do what other fathers do, no matter that they are blue. Consequently, this book contributes to the broadening of children's gender schemas (Campagnaro 2015; Soler Quiles 2015; Coats 2018). This will have an effect on their ideology and on their socialization because children will see different family patterns, in this case two-men families, as natural as traditional woman-man families.

\section{Conclusion}

The analysis of the textual and compositional metafunction in One Dad, Two Dads, Brown Dad, Blue Dads (1994) reveals that both the verbal and the visual modes contribute to the construction of meaning and to the representation of a twofather family using the fantasy strategy of portraying both fathers as blue. The normalization of the life of the two fathers portrays this family type as similar to others, with the exception of both fathers being blue. 
Generally, the visuals illustrate the information that appears in the written text. In this sense, image and word have a complementary layout. Moreover, the visuals show both fathers in prominent positions, which contributes to giving them equal importance in the child's life and in the development of the story.

The visual representation of the two fathers suggests that they have different personalities and different roles when taking care of the child, e.g. it is significant that the child points out that only one of the two fathers cooks. In this sense, the picturebook illustrates a combination of differences and normalization: the two fathers are portrayed as different from other fathers because of being blue, but their uniqueness in the picturebook does not prevent them from representing a standard family and doing their corresponding duties as fathers. In addition, there are clear differences between them in their clothes and in the division of tasks. However, Lou's comments make it clear that apart from being blue they are like any other family.

Although the idea of Lou's fathers being different is present in the title and from the beginning of the picturebook by being represented as blue, it is emphasized that both fathers are normalized because they are represented, verbally and visually, as being able to do the same things that other fathers can do. Consequently, two-father families are promoted and presented in an egalitarian way. In this sense, this book may contribute to the socialization of children because they can perceive same-sex families in a normalized way. In fact, this book contributes to broadening children's gender schemas and to opening their ideology to different types of families.

\section{Acknowledgements}

This study was carried out as part of research project FFI2017-85306-P (The Construction of Discourse in Children's Picture Books, AMULIT), funded by the Spanish Ministry of Economy, Industry and Competitiveness.

\section{Notes} original text.

1. Capital letters appear in the
2. The examples of marked themes appear in bold. 


\section{Works Cited}

Arizpe, Evelyn, Maureen FArrell and Julie McAdam. (eds.) 2013. Picturebooks: Beyond the Borders of Art, Narrative, and Culture. New York: Routledge.

Campagnaro, Marnie. 2015. "These Books Made Me Really Curious'. How Visual Explorations Shape the Young Readers' Taste". In Evans, Janet (ed.) Challenging and Controversial Picture Books. Creative and Visual Responses to Visual Texts. London: Routledge: 121-143.

COATS, Karen. 2018. "Gender in Picturebooks". In Kümmerling-Meibauer, Bettina (ed.): 119-127.

DANEŠ, František. 1974. "Functional Sentence Perspective and the Organization of the Text". In Daneš, František (ed.) Papers on Functional Sentence Perspective. Prague: Academia: 106-128.

Evans, Janet. (ed.) 2015. Challenging and Controversial Picturebooks: Creative and Critical Responses to Visual Texts. London: Routledge.

HallidaY, Michael A.K. and Christian M.I.M. Matthiessen. (1985) 2004. An Introduction to Functional Grammar. London: Arnold.

Hestbeek Andersen, Thomas, Morten Boerils, Eva MaAeger $\varnothing$ and Elise Seip Tønnessen. 2015. Social Semiotics: Key Figures, New Directions. London: Routledge.

Hoster Cabo, Beatriz, María José Lobato Suero and Alberto Manuel RuIz CAmpos. 2018. "Interpictoriality in Picturebooks". In Kümmerling-Meibauer, Bettina (ed.): 91-102.

Kress, Gunther and Theo van LeEuWEN. (1996) 2006. Reading Images: The Grammar of Visual Design. London: Routledge Press.

Kümmerling-Meibauer, Bettina. (ed.) 2018. The Routledge Companion to Picturebooks. New York: Routledge.

LeWIS, David. 2001. Reading Contemporary Picturebooks: Picturing Text. London: Routledge.
Mathesius, Vilem. 1975. A Functional Analysis of Present-Day English on a General Linguistic Basis. Ed. by J. Vachek. Trans. L. Dusková. The Hague: Mouton.

Moya Guijarro, Arsenio Jesús. 2014. A Multimodal Analysis of Picture Books for Children. A Systemic Functional Approach. London: Equinox.

Moya Guijarro, Arsenio Jesús. 2019a. "Communicative Functions of Visual Metonymies in Picture Books Targeted at Children in Two Different Age Groups. A Multimodal Analysis". WORD 65 (4): 193-212. DOI: $10.1080 / 00437956.2019 .1670932$

Moya Guijarro, Arsenio Jesús. 2019b. “Textual Functions of Metonymies in Anthony Browne's Picture Books: A Multimodal Approach". Text and Talk 39 (3): 389-413. DOI: $10.1080 / 00437956.2019 .1670932$

Nikolajeva, Maria and Carole Scott. 2001. How Picturebooks Work. New York and London: Garland Publishing.

O'Halloran, Kay L. 2011. "Multimodal Discourse Analysis". In Hyland, Ken and Brian Paltridge (eds.) The Continuum Companion to Discourse Analysis. London and New York: Continuum: 120-137.

PAINTER, Clare. 2007. “Children's Picture Books Narratives: Reading Sequences of Images". In McCabe, Anne, Mick O'Donnell and Rachel Whittaker (eds.) Advances in Language and Education. London and New York: Continuum: 40-59.

PAINTER, Clare. 2008. "The Role of Colour in Children's Picture Books: Choices in Ambience". In Unsworth, Len (ed.) New Literacies and the English Curriculum: Perspectives. London and New York: Continuum: 89-111. 
Painter, Clare. 2018. "Multimodal Analysis of Picturebooks". In Kümmerling-Meibauer, Bettina (ed.): 420-428.

PaInTer, Clare, James MARTIN and Len UnsWORTH. 2013. Reading Visual Narratives. Image Analysis of Children's Picture Books. London: Equinox.

PARODI, Giovanni. 2012. “University Genres and Multisemiotic Features: Accessing Specialized KnowledgeThrough Disciplinarity". Fórum Linguístico 9 (4): 259-282.

Pastoreau Michel. 2008. Black: The History of a Colour. Princeton: Princeton U.P.

SerafiNI, Frank. 2010. "Reading Multimodal Texts: Perceptual, Structural and Ideological Perspectives". Children's Literature in Education 41 (2): 85-104.

SOler Quiles, Guillermo. 2015. “La representación de la diversidad afectivosexual en la literatura infantil y juvenil de 72.

Soto Reatiga, Myriam. 2017. “El cuento como mediación pedagógica para el fortalecimiento de la lectoescritura". Zona Próxima 27: 51-65. DOI: 10.14482/zp.27.10979

Sunderland, Jane and Mark McLashan. (2011) 2012. "Stories Featuring Two-Mum or TwoDad Families". In Sunderland, Jane (ed.) Language, Gender and Children's Fiction. London and New York: Continuum: 142-172.

Thibault, Paul J. 2000. “The Multimodal Transcription of Television Advertisement: Theory and Practice." In Baldry, Anthony (ed.) Multimodality and Multimediality in the Distance Learning Age. Campobasso: Palladino Editore: 311-385.

UNSWORTH, Len and Isabel OrTIGAS. 2008. "Exploring the Narrative Art of David Wiesner: Using a Grammar of Visual Design and Learning Experiences on the World Wide Web". L1 - Educational Studies in Language and Literature 8 (3): 1-21.

UNSWORTH, Len. 2014. "Multimodal Reading Comprehension: Curriculum Expectations and Large-Scale Literacy Testing Practices". Pedagogies: An International Journal 9 (1): 26-44.

Valentine, Johnny. 1994. One Dad, Two Dads, Brown Dad, Blue Dads. Illustrated by Melody Sarecky. Los Angeles: Alyson Wonderland.

VAN Leeuwen, Theo. 2011. The Language of Colour. An Introduction. London: Routledge.

van Lierop-Debrauwer, Helma. 2018. “Hybridity in Picturebooks". In Kümmerling-Meibauer, Bettina (ed.): 81-90.

Ventola, Eija and Arsenio Jesús Moya GuiJarro. (eds.) 2009. The World Told and the World Shown: Multisemiotic Issues. Hampshire: Palgrave Macmillan. 